Bangladesh J. Bot. 48(1): 177-186, 2019 (March)

\title{
CHANGES IN PEROXIDASE AND POLYPHENOL OXIDASE ACTIVITY AND TRANSCRIPT LEVELS OF RELATED GENES IN TWO EGYPTIAN BREAD WHEAT CULTIVARS (TRITICUM AESTIVUM L.) AFFECTED BY GAMMA IRRADIATION AND SALINITY STRESS
}

\author{
Amina Abd El-Hamid Aly*, Rabab Waheed Maraei and Ibrahim Aldrussi ${ }^{1}$ \\ Natural Products Department, National Centre for Radiation Research and Technology, \\ Atomic Energy Authority, Nasr City, Cairo, Egypt
}

Keywords: Peroxidase, Polyphenol oxidase, Gamma irradiation, Gene expression, Salinity, Wheat

\begin{abstract}
The effect of gamma irradiation (100, 200, and $300 \mathrm{~Gy})$ and $\mathrm{NaCl}(60$ and $120 \mathrm{mM})$ on peroxidase (POD) and polyphenol oxidase (PPO) activities in Sids-1 and Sakha-93 wheat cultivars were investigated. POD and PPO activities increased significantly with increasing $\mathrm{NaCl}$ concentrations, and the maximal activity increased at $120 \mathrm{mM} \mathrm{NaCl}$, while PPO activity was higher than POD at the same concentration of $\mathrm{NaCl}$ in both the two cultivars. POD and PPO isozymes profile revealed a total of six bands, whereas all of them are variable and exposed the effect of gamma ray and sodium chloride with different genetic response of the two wheat cultivars. The expression level of POD gene in Sakha-93 cultivar was more than in Sids-1. While it was more pronounced at $120 \mathrm{mM} \mathrm{NaCl}$ combined with gamma irradiation dose $300 \mathrm{~Gy}$. Gamma ray can be used as a useful tool for gene expression in plants and salt tolerance could be attributed to the constitutive induced antioxidant gene, leading to more efficient enzyme stimulation and protection in wheat.
\end{abstract}

\section{Introduction}

Plants grown on environmental stresses implicate salinity, water logging and drought, temperature, radiation, mineral deficiency or excess, suffer tremendously qualitatively and quantitatively. Although assessment of the effects of all various stresses on plants is significant, in view of the running literature, the researchers concentrate their interests on salinity than on other stresses. This is sufficient to the fact that vast area of the available land on the globe including a large number of countries is affected by salinity (Deinlein et al. 2014). Gamma irradiation is considering one of most common physical mutagens worth major effects on biochemical and physiological style in plants (Begum and Dasgupta 2011). Gamma rays have been demonstrated economical and effective as compared to other ionizing radiations because of its easy availability and the power of penetration. This penetration power of gamma irradiation helps in its broad application for the advancement of different plant species. Also, gamma radiation can interact with atoms and molecules to create oxidative stress with over production of reactive oxygen, which are able to modify important components of plant cells (Ali et al. 2016). To avoid oxidative damage, plants have evolved various protective mechanisms to counteract the effects of reactive oxygen species in cellular compartments (Pandey et al. 2017). Antioxidant defense enzymes such as superoxide dismutase (SOD), catalase (CAT), and peroxidase (POD) are the systems designed to minimize the concentrations of superoxide and hydrogen peroxide.

Previously it was reported that the activity of antioxidant enzymes in plants subjected to salt stress increased (Caverzan et al. 2016). In order to improve the performance of crops growing under salt stress, it is important to understand how plants cope under such conditions. Salt

*Author for correspondence: <aly_amina@yahoo.co.uk>. ${ }^{1}$ Evolutionary Genetics Department of Botany, Fac. Science, Benghazy Uni. Lybia. 
tolerance of plants is a complex phenomenon that involves physiological, biochemical, and molecular processes as well as morphological. Furthermore, salinity tolerance is unlikely to be determined by a single gene or gene product (Cai et al. 2017). There is an extensively applied technique in molecular plants can be used for quantification of different enzymes gene expression activities (RT-PCR, Real Time PCR) and proved to be a successful tool for evaluation the possible resistance genes in wheat (El-Argawy and Adss 2016). The aim of the present study was to investigate the effects of gamma irradiation and sodium chloride stress on peroxidase and polyphenol oxidase enzyme activities and their isozymes profile. In addition quantification of the level of their genes expression using real-time PCR in two Egyptian bread wheat cultivars Sids-1 and Sakha-93 was conducted.

\section{Materials and Methods}

Grains of the two Egyptian bread wheat cultivars; Sids-1 and Sakha-93 used in the present study were obtained from Agricultural Research Centre, Ministry of Agriculture, Giza, Egypt. Two cultivars were irradiated with gamma rays doses $(0.0,100,200$ and $300 \mathrm{~Gy}$ with a dose rate of: $1.9 \mathrm{kGy} / \mathrm{h}$ ). The source of irradiation installed at the National Center for Radiation Research and Technology, Atomic Energy Authority, Nasr City, Cairo, Egypt. Irradiated and un-irradiated grains were sown (Aly et al. 2018) to get $\mathrm{M}_{1}$ of the grains. To raise $\mathrm{M}_{2}$ generation, random grain samples main spikes were taken from bulked $\mathrm{M}_{1}$ generation grains for each irradiation dose. These samples were sown in pots for 10 days and after that transferred to hydroponic system and irrigated with $\mathrm{NaCl}$ at concentrations $(0.0,60$ and $120 \mathrm{mM} \mathrm{NaCl} / \mathrm{l})$. After 45 days from subjected to salt stress, root samples were taken for estimating the following analyses.

Enzyme extraction from roots sample $(0.5 \mathrm{~g})$ of each treatment was prepared by homogenizing in $100 \mathrm{mM}$ pre-chilled sodium phosphate buffer $(\mathrm{pH} 7.0)$ containing $0.1 \mathrm{mM}$ EDTA and $1 \%$ polyvinyl pyrrolidone $(\mathrm{PVP})(\mathrm{w} / \mathrm{v})$ at $4^{\circ} \mathrm{C}$. The extraction ratio was $4.0 \mathrm{ml}$ buffer for each $1.0 \mathrm{~g}$ of roots tissue. The homogenate was centrifuged at $15.000 \times \mathrm{g}$ for $15 \mathrm{~min}$ at $4^{\circ} \mathrm{C}$. Supernatant was used to estimate the activities of peroxidase and polyphenol oxidase. Protein content was determined in the enzymes extract according to Bradford (1976).

Peroxidase (POD) was assayed by the method described by Hammerschmidt et al. (1982). The enzyme activity was expressed as unit/min/mg protein.

Polyphenol oxidase (PPO) was assayed using the method of Oktay et al. (1995). The enzyme activity was expressed as unit/min/mg protein.

Banding pattern profile of peroxidase and polyphenyl oxidase was done by the methods as described by Jonathan and Weeden (1990). Estimation of quantitative of peroxidase and polyphenol oxidase genes expression were done by using RT-qPCR.

RNA isolation was prepared according to the manufacture procedure, total RNA was extracted from plant tissue using GStract ${ }^{\mathrm{TM}}$ RNA Isolation kit II (Guanidium Thiocynate).

Reverse transcription (RT) or first strand reaction was conducted for converting the mRNA to complementary DNA (cDNA) in the presence of deoxynucleotide triphosphates (dNTPS) and reverse transcriptase. The compositions were combined with DNA primer in a reverse transcriptase buffer for $1 \mathrm{hr}$ at $42^{\circ} \mathrm{C}$. The exponential amplification via reverse transcription polymerase chain reaction supplied a highly sensitive technique, where a very low copy number of RNA molecules can be identified.

Plant samples were analyzed using the Fermentase kit: Every reaction contained $12.5 \mu 1$ of $2 \mathrm{x}$ Quantitech SYBR ${ }^{\circledR}$ Green RT Mix, $1 \mu 1$ of $25 \mathrm{pm} / \mu$ l forward primer (Table 1), $1 \mu 1$ of $25 \mathrm{pm} / \mu \mathrm{l}$ reverse primer, $1 \mu \mathrm{l}$ of the cDNA ( $50 \mathrm{ng}$ ), $9.25 \mu \mathrm{l}$ of RNase free water for a total of $25 \mu \mathrm{l}$. The real time PCR program was as follows: initial denaturation at $95^{\circ} \mathrm{C}$ for $10 \mathrm{~min}$.; 40 cycles at $95^{\circ} \mathrm{C}$ for 
$15 \mathrm{sec}$; annealing at $60^{\circ} \mathrm{C}$ for $30 \mathrm{sec}$ and extension at $72^{\circ} \mathrm{C}$ for $30 \mathrm{sec}$. Data acquisition was performed during the extensive step. This reaction was performed using Rotor-Gene- 6000 -system (Qiagen, USA).

Table 1. Sequence of primers used in the real-time PCR.

\begin{tabular}{llc}
\hline Primers & Primer sequence $(5 \rightarrow 3)$ & Annealing $\left({ }^{\circ} \mathrm{C}\right)$ \\
\hline Peroxidase (F) & CTCGACCTACAAGGAC & 60 \\
Peroxidase (R) & ATGTAGGCGCTGGTGA & \\
Polyphenol oxidase (F) & GCTTTGTCAGGGGTTGTGAT & 60 \\
Polyphenol oxidase (R) & TGCATCTCTAGCAACCAACG & \\
\hline
\end{tabular}

$\mathrm{F}=$ Forward primer, $\mathrm{R}=$ Reverse primer.

A complete randomized blocks design with three replicates was used. Analysis of variance (ANOVA) and Duncan's multiple range method were used to compare the significant differences between the different treatments. Values were expressed as means \pm standard deviations (Duncan $1955)$ to compare the results of the experiments $(\mathrm{p} \leq 0.05)$. All samples dataset of real-time PCR data were analyzed with adequate bioinformatics and statistical program for the estimation of the relative expression of genes using real-time PCR and the result normalized to ITS housekeeping gene (Reference gene). The data were statistically evaluated, interpreted and analyzed using Rotor- Gene-6000 version 1.7 (Rasmussen 2001).

\section{Results and Discussion}

Plants differed greatly in their tolerance to salinity, as reflected in their different growth responses. The effect of different dose levels 100, 200, and 300 Gy as well as different concentrations of sodium chloride on peroxidase (POD) and polyphenol oxidase (PPO) activities in two Egyptian bread wheat cultivars (Sids-1 and Sakha-93) are presented in Figs. 1 and 2. The activities of POD and PPO increased significantly with increasing $\mathrm{NaCl}$ concentrations, and the maximal levels increased at $120 \mathrm{mM}$ of $\mathrm{NaCl}$ concentration, while the activity of PPO was higher than POD at the same concentration of $\mathrm{NaCl}$ in the both two cultivars. Same trend was
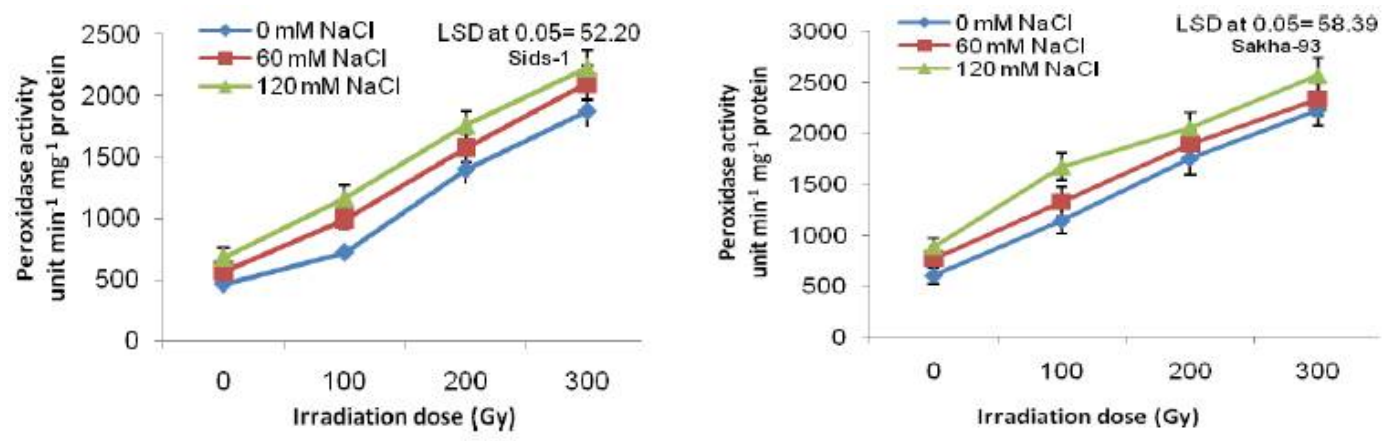

Fig. 1. Effect of sodium chloride and gamma irradiation on peroxidase activity in Sids-1 and Sahka-93 cultivars.

observed in irradiated treatments and also when gamma irradiation combined with $\mathrm{NaCl}$ different concentrations, highest specific activity of peroxidase (2218.62 and $2563.59 \mathrm{unit} / \mathrm{min} / \mathrm{mg}$ protein) was recorded in the treatment $300 \mathrm{~Gy}+120 \mathrm{mM} \mathrm{NaCl}$ for Sids- 1 and Sakha-93 cultivars, respectively, which were significantly higher than that of the control sample. Induction of SOD 
and POD by irradiation would be one of the defense systems activated ROS-mediated cellular signaling (Vanhoudt et al. 2014). Enhancement in peroxidase activity by radiation has also been reported by Ling et al. (2013) in Oryza sativa. According to the present results, correlation effect of antioxidant enzyme scavenging mechanisms is vital to overcome salinity stress in wheat.
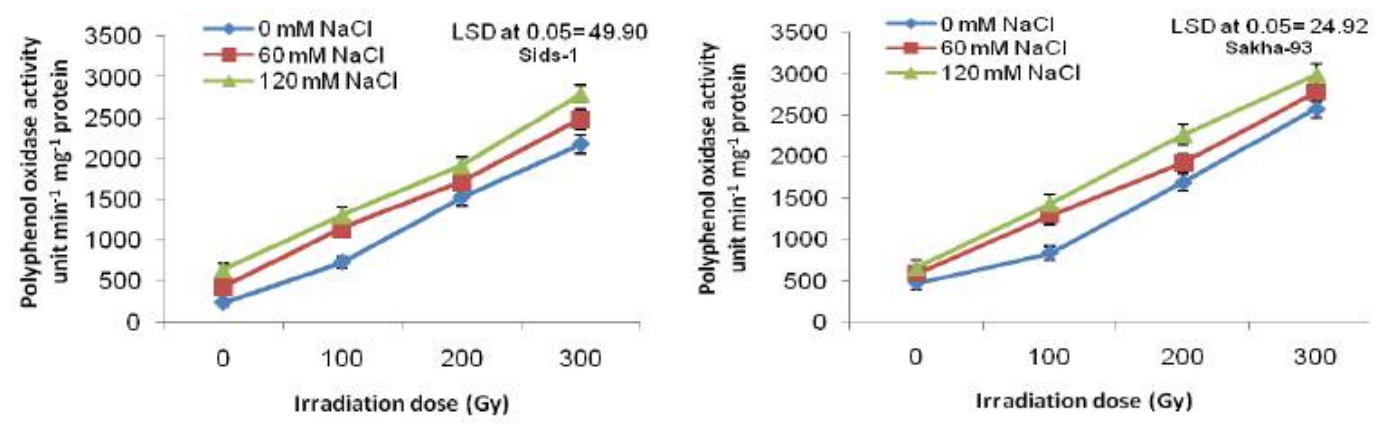

Fig. 2. Effect of sodium chloride and gamma irradiation on polyphenol oxidase activity in Sids-1 and Sahka93 cultivars.

After the native polyacrylamide gel electrophoresis (PAGE) analysis, up to six POD distinct isozymes in both the two cultivars Sids-1 and Sakha-93 were identified (Figs. 3 and 4) and (Tables 2 and 3). Also, isozymes analysis for PPO revealed a total of six bands, whereas all of them were variable and exposed the effect of gamma ray and salinity with different genetic response of the two wheat cultivars (Figs. 5 and 6) and (Tables 4 and 5). The salt-stressed roots were highly capable of increasing the number and intensity of POD isoforms.

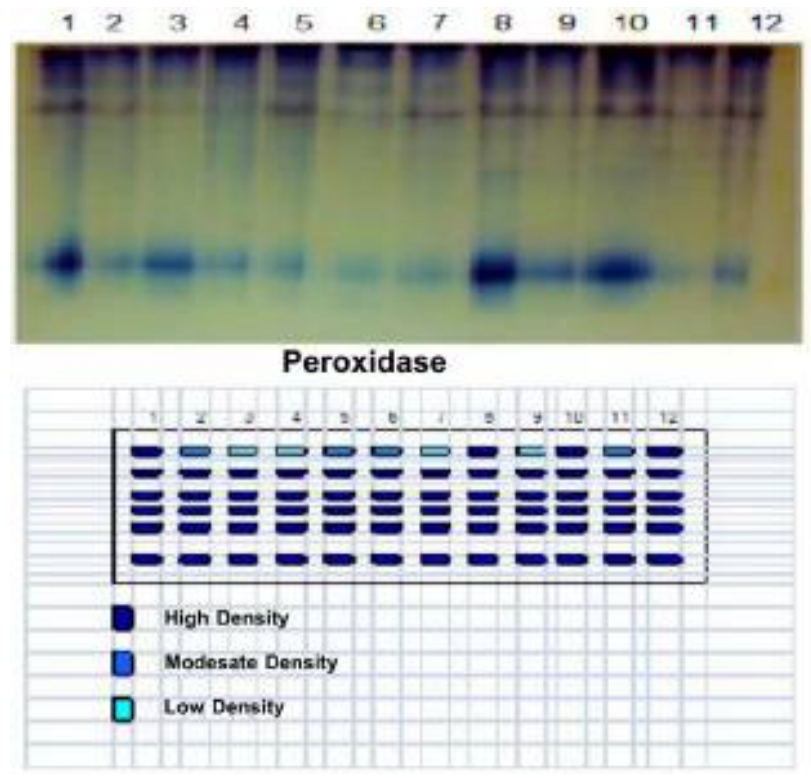

Fig. 3. Electrophoretic patterns in Sides-1 wheat cultivar for POD isozymes under control and different treatments. Lane 1 $=($ control), lane $2=60 \mathrm{mM} \mathrm{NaCl}$, lane $3=120 \mathrm{mM} \mathrm{NaCl}$, lane $4=100 \mathrm{~Gy}$, lane $5=100 \mathrm{~Gy}+60 \mathrm{mM} \mathrm{NaCl}$, lane $6=$ $100 \mathrm{~Gy}+120 \mathrm{mM} \mathrm{NaCl}$, lane $7=200 \mathrm{~Gy}$, lane $8=200 \mathrm{~Gy}+60 \mathrm{mM} \mathrm{NaCl}$, lane $9=200 \mathrm{~Gy}+120 \mathrm{mM} \mathrm{NaCl}$, lane $10=$ $300 \mathrm{~Gy}$, lane $11=300 \mathrm{~Gy}+60 \mathrm{mM} \mathrm{NaCl}$ and lane $12=300 \mathrm{~Gy}+120 \mathrm{mM} \mathrm{NaCl}$. 


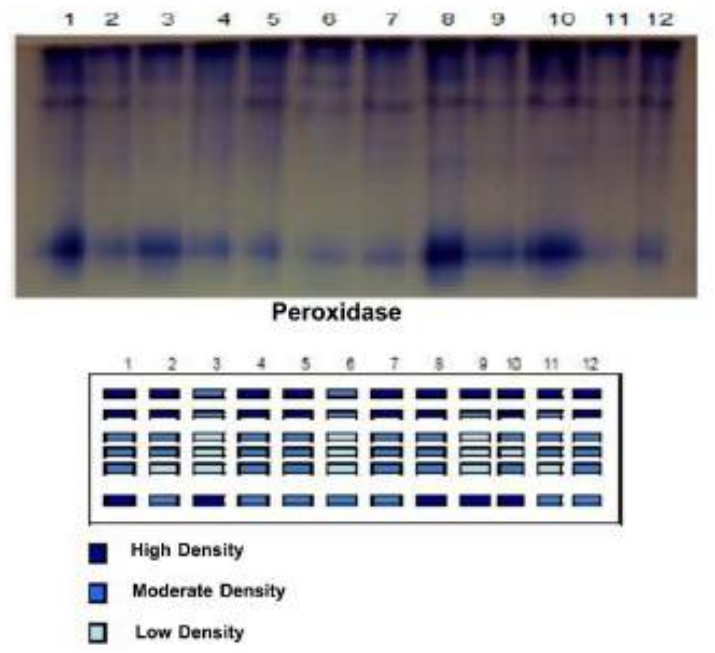

Fig. 4. Electrophoretic patterns in Sakha-93 wheat cultivar for POD isozymes under control and different treatments. Lane $1=$ (control), lane $2=60 \mathrm{mM} \mathrm{NaCl}$, lane $3=120 \mathrm{mM} \mathrm{NaCl}$, lane $4=100 \mathrm{~Gy}$, lane $5=100 \mathrm{~Gy}+60 \mathrm{mM} \mathrm{NaCl}$, lane $6=$ $100 \mathrm{~Gy}+120 \mathrm{mM} \mathrm{NaCl}$, lane $7=200 \mathrm{~Gy}$, lane $8=200 \mathrm{~Gy}+60 \mathrm{mM} \mathrm{NaCl}$, lane $9=200 \mathrm{~Gy}+120 \mathrm{mM} \mathrm{NaCl}$, lane $10=$ $300 \mathrm{~Gy}$, lane $11=300 \mathrm{~Gy}+60 \mathrm{mM} \mathrm{NaCl}$ and lane $12=300 \mathrm{~Gy}+120 \mathrm{mM} \mathrm{NaCl}$.

Table 2. Presence or absence of POD in Sids-1 wheat cultivar under control and different treatments.

\begin{tabular}{ccccccccccccccc}
\hline \multirow{2}{*}{$\begin{array}{c}\text { POD } \\
\text { groups }\end{array}$} & $\begin{array}{c}\text { Relative } \\
\text { mobility }\end{array}$ & \multicolumn{8}{c}{ Sids-1 wheat cultivar under different treatments } \\
\cline { 2 - 14 } & & 1 & 2 & 3 & 4 & 5 & 6 & 7 & 8 & 9 & 10 & 11 & 12 \\
\hline POD1 & 0.1 & $1^{-}$ & $1^{+}$ & $1^{-}$ & $1^{-}$ & $1^{+}$ & $1^{+}$ & $1^{-}$ & $1^{++}$ & $1^{-}$ & $1^{-}$ & $1^{+}$ & $1^{++}$ \\
POD2 & 0.2 & $1^{-}$ & $1^{+}$ & $1^{-}$ & $1^{-}$ & $1^{+}$ & $1^{-}$ & $1^{+}$ & $1^{+}$ & $1^{+}$ & $1^{+}$ & $1^{+}$ & $1^{+}$ \\
POD3 & 0.4 & $1^{+}$ & $1^{-}$ & $1^{-}$ & $1^{+}$ & $1^{+}$ & $1^{+}$ & $1^{+}$ & $1^{+}$ & $1^{+}$ & $1^{+}$ & $1^{+}$ & $1^{+}$ \\
POD4 & 0.5 & $1^{+}$ & $1^{-}$ & $1^{-}$ & $1^{+}$ & $1^{+}$ & $1^{+}$ & $1^{-}$ & $1^{-}$ & $1^{-}$ & $1^{-}$ & $1^{-}$ & $1^{+}$ \\
POD5 & 0.6 & $1^{-}$ & $1^{-}$ & $1^{-}$ & $1^{+}$ & $1^{+}$ & $1^{+}$ & $1^{-}$ & $1^{+}$ & $1^{+}$ & $1^{+}$ & $1^{-}$ & $1^{+}$ \\
POD6 & 0.8 & $1^{-}$ & $1^{+}$ & & $1^{+}$ & $1^{+}$ & $1^{+}$ & $1^{+}$ & $1^{-}$ & $1^{-}$ & $1^{-}$ & $1^{+}$ & $1^{+}$ \\
\hline
\end{tabular}

1 Present band 0 Absent band ++ High density + Moderate density - Low density Lane $1=($ control $)$, lane $2=60 \mathrm{mM} \mathrm{NaCl}$, lane $3=120 \mathrm{mM} \mathrm{NaCl}$, lane $4=100 \mathrm{~Gy}$, lane $5=100 \mathrm{~Gy}+60 \mathrm{mM} \mathrm{NaCl}$, lane 6 $=100 \mathrm{~Gy}+120 \mathrm{mM} \mathrm{NaCl}$, lane $7=200 \mathrm{~Gy}$, lane $8=200 \mathrm{~Gy}+60 \mathrm{mM} \mathrm{NaCl}$, lane $9=200 \mathrm{~Gy}+120 \mathrm{mM} \mathrm{NaCl}$, lane $10=300$ Gy, lane $11=300 \mathrm{~Gy}+60 \mathrm{mM} \mathrm{NaCl}$ and lane $12=300 \mathrm{~Gy}+120 \mathrm{mM} \mathrm{NaCl}$.

Table 3. Presence or absence of POD groups in Sakha-93 under control and different treatments.

\begin{tabular}{ccccccccccccccc}
\hline POD & Relative & \multicolumn{9}{c}{ Sakha-93 wheat cultivar } \\
\cline { 3 - 14 } groups & mobility & 1 & 2 & 3 & 4 & 5 & 6 & 7 & 8 & 9 & 10 & 11 & 12 \\
\hline POD1 & 0.1 & $1^{-}$ & $1^{-}$ & $1^{+}$ & $1^{-}$ & $1^{-}$ & $1^{+}$ & $1^{-}$ & $1^{++}$ & $1^{-}$ & $1^{-}$ & $1^{-}$ & $1^{++}$ \\
POD2 & 0.2 & $1^{-}$ & $1^{-}$ & $1^{+}$ & $1^{-}$ & $1^{-}$ & $1^{+}$ & $1^{-}$ & $1^{-}$ & $1^{+}$ & $1^{-}$ & $1^{+}$ & $1^{-}$ \\
POD3 & 0.4 & $1^{+}$ & $1^{+}$ & $1^{-}$ & $1^{+}$ & $1^{+}$ & $1^{-}$ & $1^{+}$ & $1^{+}$ & $1^{-}$ & $1^{+}$ & $1^{+}$ & $1^{+}$ \\
POD4 & 0.5 & $1^{+}$ & $1^{+}$ & $1^{-}$ & $1^{+}$ & $1^{+}$ & $1^{-}$ & $1^{+}$ & $1^{+}$ & $1^{-}$ & $1^{-}$ & $1^{-}$ & $1^{+}$ \\
POD5 & 0.6 & $1^{-}$ & $1^{-}$ & $1^{-}$ & $1^{+}$ & $1^{+}$ & $1^{-}$ & $1^{+}$ & $1^{+}$ & $1^{-}$ & $1^{+}$ & $1^{-}$ & $1^{+}$ \\
POD6 & 0.8 & $1^{-}$ & $1^{+}$ & $1^{-}$ & $1^{+}$ & $1^{+}$ & $1^{+}$ & $1^{+}$ & $1^{-}$ & $1^{-}$ & $1^{-}$ & $1^{+}$ & $1^{+}$ \\
\hline
\end{tabular}

1 Present band 0 Absent band ++ High density + Moderate density - Low densit Lane $1=$ (control), lane $2=60 \mathrm{mM} \mathrm{NaCl}$, lane $3=120 \mathrm{mM} \mathrm{NaCl}$, lane $4=100 \mathrm{~Gy}$, lane $5=100 \mathrm{~Gy}+60 \mathrm{mM}$ $\mathrm{NaCl}$, lane $6=100 \mathrm{~Gy}+120 \mathrm{mM} \mathrm{NaCl}$, lane $7=200 \mathrm{~Gy}$, lane $8=200 \mathrm{~Gy}+60 \mathrm{mM} \mathrm{NaCl}$, lane $9=200$ $\mathrm{Gy}+120 \mathrm{mM} \mathrm{NaCl}$, lane $10=300 \mathrm{~Gy}$, lane $11=300 \mathrm{~Gy}+60 \mathrm{mM} \mathrm{NaCl}$ and lane $12=300 \mathrm{~Gy}+120 \mathrm{mM} \mathrm{NaCl}$. 


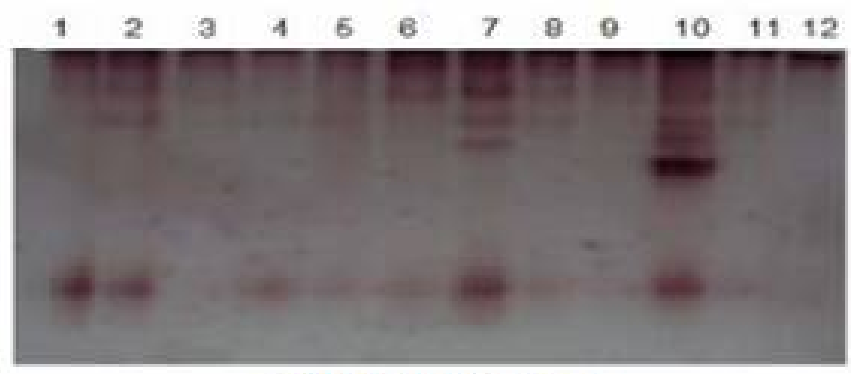

Polyphenol oxidase

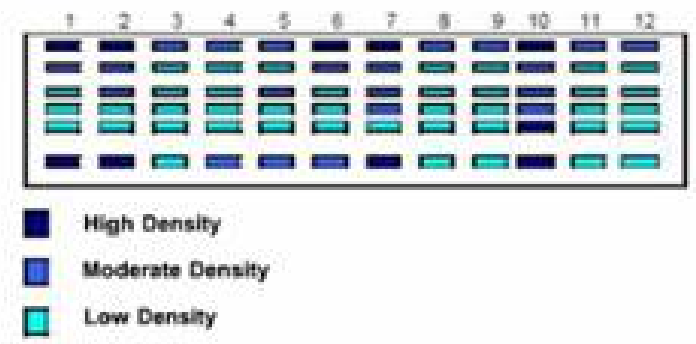

Fig. 5. Electrophoretic patterns in Sids-1 wheat cultivar for PPO isozymes under control and different treatments. Lane $1=$ (control), lane $2=60 \mathrm{mM} \mathrm{NaCl}$, lane $3=120 \mathrm{mM} \mathrm{NaCl}$, lane $4=100 \mathrm{~Gy}$, lane $5=$ $100 \mathrm{~Gy}+60 \mathrm{mM} \mathrm{NaCl}$, lane $6=100 \mathrm{~Gy}+120 \mathrm{mM} \mathrm{NaCl}$, lane $7=200 \mathrm{~Gy}$, lane $8=200 \mathrm{~Gy}+60 \mathrm{mM}$ $\mathrm{NaCl}$, lane $9=200 \mathrm{~Gy}+120 \mathrm{mM} \mathrm{NaCl}$, lane $10=300 \mathrm{~Gy}$, lane $11=300 \mathrm{~Gy}+60 \mathrm{mM} \mathrm{NaCl}$ and lane 12 $=300 \mathrm{~Gy}+120 \mathrm{mM} \mathrm{NaCl}$.

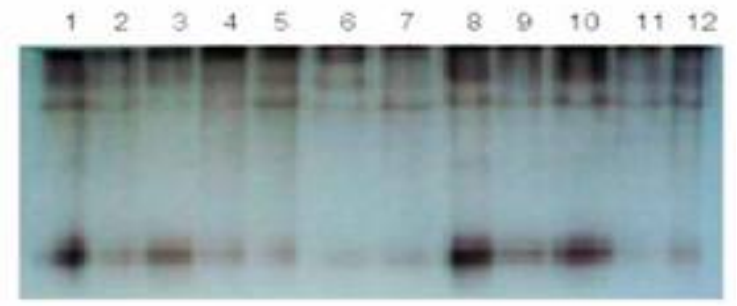

Polyphenol oxidase

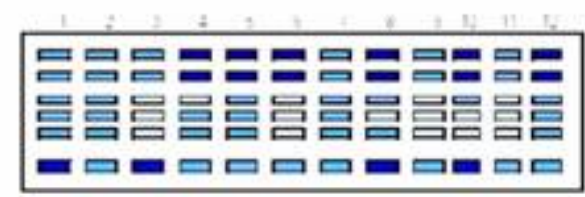

[ High Density

口 Moderate Density

$\square$ Low Density

Fig. 6. Electrophoretic patterns in Sakha-93 wheat cultivar for PPO isozymes under control and different treatments. Lane $1=($ control $)$, lane $2=60 \mathrm{mM} \mathrm{NaCl}$, lane $3=120 \mathrm{mM} \mathrm{NaCl}$, lane $4=100 \mathrm{~Gy}$, lane $5=$ $100 \mathrm{~Gy}+60 \mathrm{mM} \mathrm{NaCl}$, lane $6=100 \mathrm{~Gy}+120 \mathrm{mM} \mathrm{NaCl}$, lane $7=200 \mathrm{~Gy}$, lane $8=200 \mathrm{~Gy}+60 \mathrm{mM}$ $\mathrm{NaCl}$, lane $9=200 \mathrm{~Gy}+120 \mathrm{mM} \mathrm{NaCl}$, lane $10=300 \mathrm{~Gy}$, lane $11=300 \mathrm{~Gy}+60 \mathrm{mM} \mathrm{NaCl}$ and lane 12 $=300 \mathrm{~Gy}+120 \mathrm{mM} \mathrm{NaCl}$. 
Table 4. Presence or absence of PPO groups in Sids-1 under control and different treatments.

\begin{tabular}{ccccccccccccccc}
\hline PPO & Relative & \multicolumn{9}{c}{ Sids-1 } & \multicolumn{1}{c}{ wheat cultivar under } & different treatments & \\
\cline { 3 - 14 } groups & cobility & 1 & 2 & 3 & 4 & 5 & 6 & 7 & 8 & 9 & 10 & 11 & 12 \\
\hline PPO1 & 0.1 & $1^{-}$ & $1^{++}$ & $1^{+}$ & $1^{+}$ & $1^{+}$ & $1^{++}$ & $1^{+}$ & $1^{+}$ & $1^{+}$ & $1^{-}$ & $1^{+}$ & $1^{+}$ \\
PPO2 & 0.3 & $1^{+}$ & $1^{+}$ & $1^{-}$ & $1^{-}$ & $1^{-}$ & $1^{+}$ & $1^{+}$ & $1^{-}$ & $1^{-}$ & $1^{+}$ & $1^{-}$ & $1^{-}$ \\
PPO3 & 0.4 & $1^{-}$ & $1^{+}$ & $1^{-}$ & $1^{-}$ & $1^{+}$ & $1^{-}$ & $1^{+}$ & $1^{-}$ & $1^{-}$ & $1^{+}$ & $1^{-}$ & $1^{-}$ \\
PPO4 & 0.5 & $1^{-}$ & $1^{-}$ & $1^{-}$ & $1^{-}$ & $1^{-}$ & $1^{-}$ & $1^{+}$ & $1^{-}$ & $1^{-}$ & $1^{+}$ & $1^{-}$ & $1^{-}$ \\
PPO5 & 0.6 & $1^{-}$ & $1^{-}$ & $1^{-}$ & $1^{-}$ & $1^{-}$ & $1^{-}$ & $1^{-}$ & $1^{-}$ & $1^{-}$ & $1^{-}$ & $1^{-}$ & $1^{-}$ \\
PPO6 & 0.8 & $1^{-}$ & $1^{-}$ & $1^{-}$ & $1^{+}$ & $1^{+}$ & $1^{+}$ & $1^{-}$ & $1^{-}$ & $1^{-}$ & $1^{-}$ & $1^{-}$ & $1^{-}$ \\
\hline
\end{tabular}

1 Present band 0 absent band ++ High density + Moderate density - Low density Lane $1=$ (control), lane $2=60 \mathrm{mM} \mathrm{NaCl}$, lane $3=120 \mathrm{mM} \mathrm{NaCl}$, lane $4=100 \mathrm{~Gy}$, lane $5=100 \mathrm{~Gy}+60 \mathrm{mM}$ $\mathrm{NaCl}$, lane $6=100 \mathrm{~Gy}+120 \mathrm{mM} \mathrm{NaCl}$, lane $7=200 \mathrm{~Gy}$, lane $8=200 \mathrm{~Gy}+60 \mathrm{mM} \mathrm{NaCl}$, lane $9=200 \mathrm{~Gy}+$ $120 \mathrm{mM} \mathrm{NaCl}$, lane $10=300 \mathrm{~Gy}$, lane $11=300 \mathrm{~Gy}+60 \mathrm{mM} \mathrm{NaCl}$ and lane $12=300 \mathrm{~Gy}+120 \mathrm{mM} \mathrm{NaCl}$.

Table 5. Presence or absence of PPO groups in Saka-93 under control and different treatments.

\begin{tabular}{|c|c|c|c|c|c|c|c|c|c|c|c|c|c|}
\hline \multirow{2}{*}{$\begin{array}{c}\text { PPO } \\
\text { groups }\end{array}$} & \multirow{2}{*}{$\begin{array}{l}\text { Relative } \\
\text { mobility }\end{array}$} & \multicolumn{12}{|c|}{ Sakha-93 wheat cultivar under different treatments } \\
\hline & & 1 & 2 & 3 & 4 & 5 & 6 & 7 & 8 & 9 & 10 & 11 & 12 \\
\hline PPO1 & 0.1 & $1^{-}$ & $1^{+}$ & $1^{+}$ & $1^{-}$ & $1^{-}$ & $1^{-}$ & $1^{+}$ & $1^{-}$ & $1^{+}$ & $1^{-}$ & $1^{+}$ & $1^{-}$ \\
\hline $\mathrm{PPO} 2$ & 0.3 & $1^{-}$ & $1^{+}$ & $1^{+}$ & $1^{-}$ & $1^{-}$ & $1^{-}$ & $1^{+}$ & $1^{-}$ & $1^{+}$ & $1^{-}$ & $1^{+}$ & $1^{-}$ \\
\hline PPO3 & 0.4 & $1^{+}$ & $1^{+}$ & $1^{-}$ & $1^{-}$ & $1^{+}$ & $1^{-}$ & $1^{+}$ & $1^{+}$ & $1^{-}$ & $1^{+}$ & $1^{-}$ & $1^{+}$ \\
\hline PPO4 & 0.5 & $1^{+}$ & $1^{+}$ & $1^{-}$ & $1^{+}$ & $1^{+}$ & $1^{-}$ & $1^{+}$ & $1^{-}$ & $1^{-}$ & $1^{-}$ & $1^{-}$ & $1^{+}$ \\
\hline PPO5 & 0.6 & $1^{-}$ & $1^{-}$ & $1^{-}$ & $1^{-}$ & $1^{-}$ & $1^{-}$ & $1^{-}$ & $1^{-}$ & $1^{-}$ & $1^{-}$ & $1^{-}$ & $1^{-}$ \\
\hline PPO6 & 0.8 & $1^{-}$ & $1^{+}$ & $1^{-}$ & $1^{+}$ & $1^{+}$ & $1^{+}$ & $1^{+}$ & $1^{-}$ & $1^{+}$ & $1^{-}$ & $1^{+}$ & $1^{+}$ \\
\hline
\end{tabular}

1 Present band 0 Absent band ++ High density + Moderate density - Low density Lane $1=$ (control), lane $2=60 \mathrm{mM} \mathrm{NaCl}$, lane $3=120 \mathrm{mM} \mathrm{NaCl}$, lane $4=100 \mathrm{~Gy}$, lane $5=100 \mathrm{~Gy}+60$ $\mathrm{mM} \mathrm{NaCl}$, lane $6=100 \mathrm{~Gy}+120 \mathrm{mM} \mathrm{NaCl}$, lane $7=200 \mathrm{~Gy}$, lane $8=200 \mathrm{~Gy}+60 \mathrm{mM} \mathrm{NaCl}$, lane $9=200$ $\mathrm{Gy}+120 \mathrm{mM} \mathrm{NaCl}$, lane $10=300 \mathrm{~Gy}$, lane $11=300 \mathrm{~Gy}+60 \mathrm{mM} \mathrm{NaCl}$ and lane $12=300 \mathrm{~Gy}+120 \mathrm{mM}$ $\mathrm{NaCl}$.

This could be considered as a response to salt induced oxidative damage, suggesting the enzymatic removal of $\mathrm{H}_{2} \mathrm{O}_{2}$ by POD. The present study gave base information and a method vital to perform further studies related to the biochemical and genetic basis to detect the salt tolerance of wheat. These results are in agreement with the results reported by El-Beltagi et al. (2013) who approved that when gamma irradiation combined with salt stress, increased the activity of POD and PPO enzymes and in the same time increased the detected number of isozyme bands. In the same concern, Shen et al. (2010) demonstrated that $\gamma$-irradiation

can influence the activity and isozymatic composition of peroxidases in soybean seedling. Besides, peroxidase plays an important role in plant defense against oxidative stress by scavenging $\mathrm{H}_{2} \mathrm{O}_{2}$ in cytosol, peroxisome, mitochondria, and chloroplast of plant cells (Das and Roychoudhury 2014). Also, Zhang et al. (2013) indicated that $\mathrm{NaCl}$ stress can either stimulate or inhibit the expression of the isoforms of several antioxidant enzymes and the induction of stress-related isozymes is probably related to the level of ROS, which cause oxidative damage to the plant cells.

To conserve plant cells from oxidative damage induced by abiotic stresses such as salt stress, several genes encoding antioxidant enzymes are up organized. Therefore, analyses of the transcript levels of antioxidant defense genes can consider the achievement of their yield to the salt stress response in plants. The level expression of POD gene in wheat roots was high gene expression at $120 \mathrm{Mm} \mathrm{NaCl}$ followed by $100 \mathrm{~Gy} / 120 \mathrm{mM}$ and $100 \mathrm{~Gy} / 60 \mathrm{mM}$ in Sids-1 wheat cultivar. While Sakha-93 was high gene expression at $300 \mathrm{~Gy} / 60 \mathrm{mM}$ followed by $200 \mathrm{~Gy} / 60 \mathrm{mM}$ (Fig. 7). Data 
illustrated in Fig. 8 proved the highest values of gene expression for PPO which were higher in Sids-1 cultivar than in Sakha-93 cultivar. However, the treatments $200 \mathrm{~Gy} / 0.0 \mathrm{mM} \mathrm{NaCl}$ and $100 \mathrm{~Gy} / 0.0 \mathrm{mM} \mathrm{NaCl}$, showed the highest values. Zhang et al. (2014) reported that there was increase in antioxidant enzyme activity and in the transcript levels of genes encoding these enzymes under salt stress Limonium sinense Kuntze seedlings. The utilization of natural genetic variations and the generation of transgenic plants, introducing novel genes or altering expression levels of the existing genes are being used to improve salt tolerance (Arzani and Ashraf 2016). The high expression of certain stress response genes in plants able to achieve in a certain stress environment elicit as a probably popular adaptive mechanism.

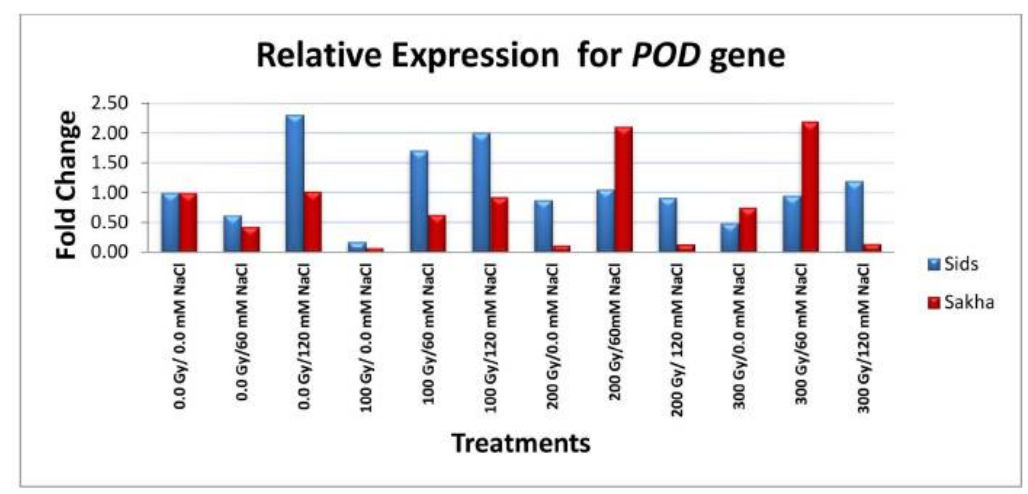

Fig. 7. Quantitative real-time RT-PCR analysis of transcript levels of peroxidase biosynthetic gene at different concentrations of sodium and under gamma irradiation stress. Relative expression for POD gene in Sids-1 and Sakha-93 wheat cultivar as affected by gamma irradiation and sodium chloride stress.

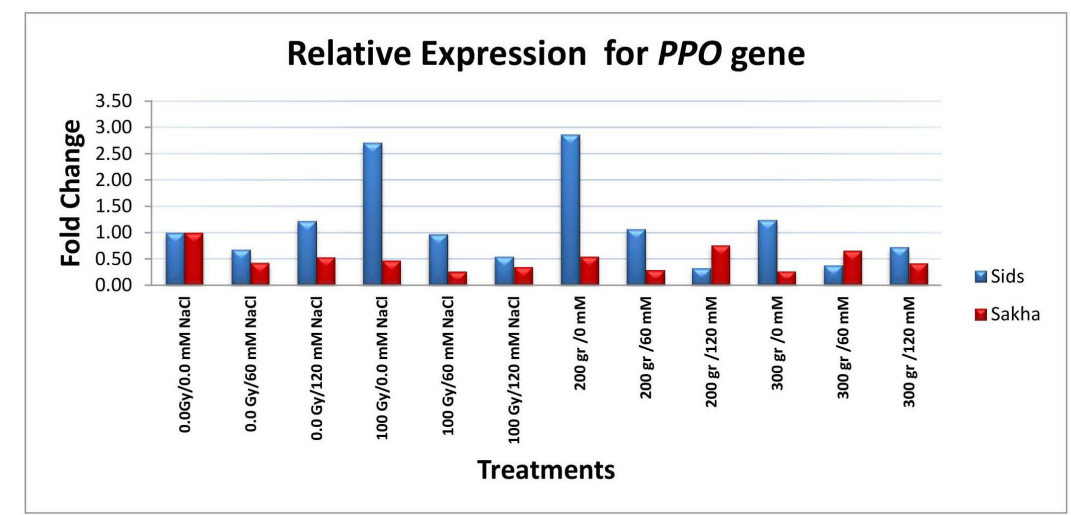

Fig. 8. Quantitative real-time RT-PCR analysis of transcript levels of polyphenol oxidase biosynthetic gene at different concentrations of sodium chloride and under gamma irradiation stress. Relative expression for PPO gene in Sids-1 and Sakha-93 wheat cultivars as affected by gamma irradiation and sodium chloride stress.

POD and PPO enzyme activities and gene expressions can be used as biochemical and molecular markers to detect the resistance or susceptibility nature of wheat cultivars against salinity in integration with gamma irradiation. The expression of many antioxidant enzymes is 
positively correlated with higher tolerance levels against abiotic stresses. The activation of some enzymes leads to plant protection against oxidative damage. Such studies demonstrate the importance of the relationship between the development of salt tolerance and antioxidant activity. This attitude may be suitable to its capability to tolerate salt stress or because of salt stress which may cause some shift in gene expression.

\section{Acknowledgements}

Authors would like to thank the Atomic Energy Authority for their support and Ministry of Scientific Research for funding this study through the frame of Tunisia-Egypt cooperation project, Fourth call, cod No. 14/4/30.

\section{References}

Ali HZ Ghori, Sheikh S and Gul A 2016. Effects of gamma radiation on crop production. In: Crop Production and Global Enviromental Issues, Springer International Publishing, Cham, Switzerland.

Aly AA, Maraei RW and Ayadi S 2018. Some biochemical changes in two Egyptian bread wheat cultivars in response to gamma irradiation and salt stress. Bulg. J. Agric. Sci. 24(1): 50-59.

Arzani A and Ashraf A 2016. Smart engineering of genetic resources for enhanced salinity tolerance in crop plants. Crit. Rev. Plant Sci. 35: 146-89.

Begum T and Dasgupta T 2011. Effect of mutagens on character association in sesame (Sesamum indicum L.). Pak J. Bot. 43: 243-251.

Bradford MM 1976. A rapid and sensitive method for the quantification of microgram quantities of protein utilizing the principle of protein-dye binding. Anal. Biochem. 72: 248-254.

Cai C, Wu S, Niu E, Cheng C and Guo W 2017. Identification of genes related to salt stress tolerance using intron-length polymorphic markers, association mapping and virus-induced gene silencing in cotton. Sci. Rep. 7: 528.

Caverzan A, Casassola A and Brammer SP 2016. Antioxidant responses of wheat plants under stress. Gen. Molec. Biol. 39: 1-6.

Das K and Roychoudhury A 2014. Reactive oxygen species (ROS) and response of antioxidants as ROSscavengers during environmental stress in plants. Front. Environ. Sci. 2: 1-13.

Deinlein U, Stephan AB, Horie T, Luo W, Xu G and Schroeder JI 2014. Plant salt-tolerance mechanisms. Trends Plant Sci. 19: 371-379.

Duncan DB 1955. Multiple range and multiple 'F' tests. Biometrics 11: 1.

El-Argawy E and Adss IA 2016. Quantitative gene expression of peroxidase, polyphenol oxidase and catalase as molecular markers for resistance against Ralstonia solanacearum. Am. J. Molec. Biol. 6: 88-100.

El-Beltagi HS, Mohamed HI, Mohammed AMA, Zaki LM and Mogazy AM 2013. Physiological and biochemical effects of $\gamma$-irradiation on cowpea plants (Vigna sinensis) under salt stress. Not. Bot. Horti. Agrobo. Cluj-Napoca 41(1): 104-114.

Hammerschmidt R, Nuckles E and Kuc J 1982. Association of enhanced peroxidase activity with induced systemic resistance of cucumber to Colletotrichum lagenarium. Physiol. Plant Pathol. 20: 73-82.

Jonathan FW and Weeden NF 1990. Visualization and interpretation of plant isozymes. Isozymes in Plant Biology. D.E. Soltis and P.S.Soltis (eds). London Chapman and Hall, 5-45.

Ling APK, Ung Ying C, Hussein S, Harun AR, Tanaka A and Yoshihiro H 2013. Morphological and biochemical responses of Oryza sativa L. (cultivar MR219) to ion beam irradiation. J. Zheijang Uni. Sci. B. 14: 1132-1143.

Oktay M, Kufrevioğlu I, Kocacaliskan I and Sakiroğlu H 1995. Polyphenol oxidase from Amasya apple. J. Food Sci. 60: 495-499. 
Pandey S, Fartyal D, Agarwal A, Shukla T, James D, Kaul T, Negi YK, Arora S and Reddy MK 2017. Abiotic Stress tolerance in plants: myriad roles of ascorbate peroxidase. Frontiers in Plant Science 8: 581.

Rasmussen R 2001. Quantification on the light cycler. In: Meuer S, Wittwer C, Nakagawara K, eds. Rapid cycle Real-time PCR, methods and applications. Springer Press, Heidelberg: 21-34.

Shen X, Li X, Li Z, Li J, Duan L and Eneji AE 2010. Growth, physiological attributes and antioxidant enzyme activities in soybean seedlings treated with or without silicon under UV-B radiation stress. J. Agr. Crp. Sci. 196(6): 431-439.

Vanhoudt N, Horemans N, Wannijn J, Nauts R, Van Hees M and Vandenhove H 2014. Primary stress responses in Arabidopsis thaliana exposed to gamma radiation. J. Environ. Radioact. 129:1-6.

Zhang M, Fang Y, Ji Y, Jiang Z and Wang L 2013. Effects of salt stress on ion content, antioxidant enzymes and protein profile in different tissues of Broussonetia papyrifera. South Afr. J. Bot. 85: 1-9.

Zhang X, Yin H, Chen S, He J and Guo S 2014. Changes in antioxidant enzyme activity and transcript levels of related genes in Limonium sinense Kuntze seedlings under $\mathrm{NaCl}$ stress. J. Chem. ID 749047.

(Manuscript received on 12 July, 2018; revised on 14 August, 2018) 